\title{
Impact of unilateral eyestalk ablation on Callinectes arcuatus (Ordway, 1863) under laboratory conditions: behavioral evaluation
}

\author{
Irma Vargas-Téllez ${ }^{1,2} \mathbb{D}$, Ruth Escamilla-Montes ${ }^{3} \mathbb{D}$, Juan F. Arzola-González ${ }^{1}$ \\ Genaro Diarte-Plata ${ }^{3} \mathbb{C}$, Antonio Luna-González ${ }^{3} \mathbb{C}$, Idalia Armenta-Leal ${ }^{4}{ }^{\mathbb{D}}$ \\ José R. Verduzco-Chávez ${ }^{4}$, José C. Román-Reyes ${ }^{1}$ (D) \& Martín Ignacio-Borrego ${ }^{1}$ \\ ${ }^{1}$ Facultad de Ciencias del Mar, Universidad Autónoma de Sinaloa, Mazatlán, Sinaloa, México \\ ${ }^{2}$ Estudiante Doctorado en Ciencias en Recursos Acuáticos, Facultad de Ciencias del Mar \\ Universidad Autónoma de Sinaloa, Mazatlán, Sinaloa, México \\ ${ }^{3}$ Instituto Politécnico Nacional, Centro Interdisciplinario de Investigación para el Desarrollo Integral Regional \\ Unidad Sinaloa, Departamento de Acuacultura, Guasave, Sinaloa, México \\ ${ }^{4}$ Estudiante Maestría en Recursos Naturales y Medio Ambiente, Instituto Politécnico Nacional \\ Centro Interdisciplinario de Investigación para el Desarrollo Integral Regional \\ Unidad Sinaloa, Departamento de Acuacultura, Guasave, Sinaloa, México \\ Corresponding author: Genaro Diarte-Plata (gdiarte@ipn.mx)
}

\begin{abstract}
Eyestalk ablation allows the removal of neurohormones that inhibit early reproduction and decreases the time to complete the molting cycle. The present study evaluated the impact of unilateral eyestalk ablation on the behavior of blue crab breeders Callinectes arcuatus in the short term under laboratory conditions. Immature male and female crabs and individuals in the intermolt stage were collected in Ohuira Bay, Ahome, Sinaloa, Mexico. Three bioassays were performed: males, females, and male-females each with three treatments; control + xylocaine $(50 \mu \mathrm{L}, 5 \%)$, squash ablation + xylocaine $(50 \mu \mathrm{L}, 5 \%)$, ablation by string ligation + xylocaine $(50 \mu \mathrm{L}, 5 \%)$, each with three replicas and three periods of evaluation after the ablation procedure $(10$ min, $2 \mathrm{~h}$, and $24 \mathrm{~h}$ ). Kruskal-Wallis and Chi-square $(\chi 2)$ tests were used to evaluate significances $(P<0.05)$ in the behavior of $C$. arcuatus. The sizes of blue crab $C$. arcuatus were $9.72 \pm 1.0 \mathrm{~cm}$ of carapace width. The feeding behavior of the male-females bioassay was significant at $2 \mathrm{~h}(P<0.05)$. The results obtained were satisfactory using two techniques, unilateral eyestalk ablation by squash and ligation in which pain and aggressiveness indicators were mitigated. Disorientation and aggressiveness in males were significant at $2 \mathrm{~h}$ $(P<0.05)$, and in females after $10 \mathrm{~min}$, and $2 \mathrm{~h}$ after ablation $(P<0.05)$. In the male-females bioassay, aggressiveness was significant at $2 \mathrm{~h}(P<0.05)$. Courtship and copulation were recorded in those crabs subjected to unilateral eyestalk squash ablation (13 and 8 , respectively).
\end{abstract}

Keywords: Callinectes arcuatus; eyestalk ablation; aggressiveness; mating; hormones; aquaculture

\section{INTRODUCTION}

Aquaculture represents one of the most important activities for the supply of food, in addition, together with fishing, portrays the means of subsistence of 10 to $12 \%$ of the world's population (FAO 2014). The cultivation of high commercial value species has generated great interest in recent times. So, alternatives are sought in developing this activity through technology implementation that maximizes their potential from the productive point of view, leads to research in areas such as nutrition, pathology, genetics, biochemistry, and endocrinology, among others, to improve the breeders' quality and design of new technologies that allow increasing production in terms of reproduction, growth, and number of larvae (Momin \& Rangneker 1975, Tsukimura 2001). The endocrine system of crustaceans is made up of neurosecretory cells, neurohemal organs, and endocrine glands. Neurosecretory cells are in the X-organ of the ocular

Corresponding editor: Jesús Ponce-Palafox 
peduncle and the subesophageal, thoracic, and abdominal ganglia. The neurohemal organs are named: sinus gland, pericardial organ, and postcommissural organs. The Y-organ, the mandibular organ, the androgenic gland, and the ovaries make up the endocrine glands (Fingerman 1997, Subramoniam 2000, Techa et al. 2015).

Controlled maturation and reproduction in a hatchery environment are important aspects that contribute to the success of the cultivation of crustacean species (Ogle 1991). One of the most recurrent practices in the reproduction laboratories of these organisms is the unilateral eyestalk ablation which induces ovarian maturation and spawning in breeders, particularly females (Zaib-Un-Nisa \& Ahmed 2001). The induction method is considered to improve larval production (Racotta et al. 1998, Palacios et al. 1999), but information on this procedure's physiological and metabolic effects is scarce (Rajesh \& Laxminaryana 1993, Racotta et al. 1998). It may be that the event of unilateral eyestalk ablation causes stress in these animals, which will result in an increase in their breathing rate and decrease in the level of metabolic activity compared to the unablated organisms (Rosas et al. 1993).

The unilateral ablation of the ocular peduncle, which is the most common and effective way to induce ovarian maturation, spawning, and molting in many species of penaeid shrimp (Fenucci 1988, Browdy 1992), is based on the laceration and clearing of one of the ocular globes from the eyestalk, which results in the removal of the neurosecretory X-organ/sinus gland, present in this structure. The gland is responsible for synthesizing and releasing the gonad-inhibiting hormone $(\mathrm{GIH})$, among other neurohormones of great metabolic importance (Makinouchi \& Primavera 1987, Subramoniam 2000). In addition, the removal of the neurosecretory complex makes it possible to accelerate the maturation process of the gonad, highlighting the presence of hormonal factors responsible for regulating both reproduction and various physiological processes (Fingerman 1987, Lachaise et al. 1989, Quackenbush 1991, Tsukimura 2001).

In some studies, in crustaceans such as Penaeus vannamei and Macrobrachium americanum, ablation is performed by various methods such as ligation or cutting off the ocular peduncle, followed by cauterization and the use of anesthetic and a clotting agent to minimize pain (Taylor et al. 2004, Diarte-Plata et al. 2012). The eyestalk's ablation allows removing the neurohormones that inhibit early reproduction, gonadal maturation, and the decrease of the time needed to complete the molting cycle, which causes acceleration of these processes. In this sense, many of the functions such as reproduction, molting, feeding, growth, survival, efficiency in food conversion, metabolic processes, and behavior of the breeders, among others, can be affected, depending on the species and on the physiological state of the organism (Travis 1952, Sochasky et al. 1973, Juinio-Meñez \& Ruinata 1996, Mykles 2001, Aguiñaga-Cruz et al. 2012, Diarte-Plata et al. 2012, Shinozaki-Mendes et al. 2013).

Stimuli act directly or indirectly on the neuroendocrine system or integrating centers to stimulate or inhibit the secretion of hormones that control reproduction (activation and growth of the ovaries) and molt. For example, eyestalk ablation produces vitellogenin synthesis in most female crustaceans under appropriate conditions (Choy 1987, Quackenbush 1994, Taketomi et al. 1997). In addition, the level of ecdysteroids in the hemolymph increases immediately in crabs after the ablation of the ocular peduncle (Webster \& Keller 1986). Few studies of the effect of ablation on the management of breeders of Callinectes arcuatus, so the objective of this study was to determine the short-term impact of unilateral eyestalk ablation on the conditioning (behavior) of blue crab breeders $C$. arcuatus under laboratory conditions.

\section{MATERIALS AND METHODS}

\section{Sampling, transport, and conditioning of organisms}

Blue crabs $C$. arcuatus were captured in Ohuira Bay, in the Paredones fishing field, in Ahome, Sinaloa, Mexico, in February 2019. Crab pots "aros jaiberos" (30 in a line hauler) were placed at 06:00 h. The organisms were transported in plastic coolers with seawater and continuous aeration to the Interdisciplinary Research Center for Regional Integral Development (CIIDIR) in Guasave, Sinaloa, Mexico.

Crabs were acclimated for $24 \mathrm{~h}$, in $2000 \mathrm{~L}$ tanks with a salinity 30 , at a water temperature of $26^{\circ} \mathrm{C}$, and dissolved oxygen greater than $5 \mathrm{mg} \mathrm{L}^{-1}$. In addition, the organisms were fed with fish fillets (Oreochromis sp.) twice a day; the leftovers were removed to avoid deterioration of water quality (Zamora et al. 2005).

\section{Experimental design}

\section{Ablation bioassays in males, females, and male- females}

Ninety intermolt and immature organisms per experiment (males, females, male-females) were used to analyze the effect on $C$. arcuatus behavior caused by unilateral eyestalk ablation by squash (ST) and ligation (LT) treatments (Cheng 1992). The biometrics of the individuals used were performed, considering the width 
and length of the carapace $(\mathrm{cm})$ (Mitutoyo $^{\circledR}$ digital caliper) and the total weight (g) (Ohaus ${ }^{\circledR}$ digital scale). Crabs with a carapace width of $9.72 \pm 1.0 \mathrm{~cm}$, a carapace length of $4.92 \pm 0.45 \mathrm{~cm}$, and an average weight of $73.78 \pm 20.2 \mathrm{~g}$ were used. They were divided randomly $\left(\mathrm{n}=10\right.$ ind $\left.\operatorname{tank}^{-1}\right)$ under squash and ligation treatments in a control group.

The organisms were anesthetized with xylocaine (AstraZeneca ${ }^{\circledR}$ 5\% gel, Naucalpan de Juárez, Estado de México, Mexico), which was applied to spread it over the ocular peduncle, being the treatments as follows (Diarte-Plata et al. 2012):

- Treatment I (C, control group): xylocaine $(50 \mu \mathrm{L}$, $5 \%$ ).

- Treatment II (ST): xylocaine $(50 \mu \mathrm{L}, 5 \%)+$ squash ablation: incision in the periphery of the right eye with a surgical scalpel, removing the contents from the traumatized area.

- Treatment III (LT): xylocaine $(50 \mu \mathrm{L}, 5 \%)+$ ablation with a string: ligation of the basal part of the right ocular peduncle to stop the hormonal flux.

Each treatment was performed with three replicas, each bioassay lasting $24 \mathrm{~h}$.

The experiment began at 09:00 h. Individuals in each treatment were marked on the back of the carapace with a permanent marker and placed inside $500 \mathrm{~L}$ tanks filled with $240 \mathrm{~L}$ of water. In each tank, 10 PVC shelters with 6 inches in diameter were placed at a temperature of $26^{\circ} \mathrm{C}$, salinity $35, \mathrm{pH} 8.0$, and dissolved oxygen $>5 \mathrm{mg} \mathrm{L}^{-1}$. The crabs were fed with $1 \mathrm{~g}$ pieces of tilapia (Oreochromis sp.) ad libitum. The cleaning of the tanks was carried out daily before each feeding. Water temperature, salinity, $\mathrm{pH}$, and dissolved oxygen were recorded in each tank in the morning and afternoon. Water replacements were $30 \%$ of the total volume during the bioassays.

Individual and group behaviors were observed directly and continuously as the ablated crabs were placed inside the tanks $(\mathrm{T} 0=$ first $10 \mathrm{~min})$ during the first $2(\mathrm{~T}=2)$ and $24 \mathrm{~h}(\mathrm{~T} 3=24 \mathrm{~h})$ after the eyestalk ablation to determine the level of affectation caused by the treatment. As each crab was marked, variables on behavior were recorded considering the number of the organism in each treatment. The variables on behavior are described (Table 1).

\section{Statistical analysis}

Kruskal-Wallis tests were performed for the feeding, movement, disorientation, and rest groups. For the aggressiveness behavior, Chi-square tests $\left(\chi^{2}\right)$ were applied on the aggressiveness scales $(0,1,2,3,4)$ included in the treatments [C, ST, and LT] for males, females, and male-females. All tests with an Alpha value of 0.05 (Zar 2010).

\section{RESULTS}

\section{Bioassays of crab males of Callinectes arcuatus Feeding}

Males in the feeding group showed an increase in activity after ablation at $10 \mathrm{~min}$. In the three ablation treatments (C, ST, LT) the number of actions performed by the crabs were similar $(\mathrm{C}=3.77 \%$, $\mathrm{ST}=$ $3.91 \%, \mathrm{LT}=4.02 \%)$. In the three treatments, the movement of the right and left maxilliped (1.55\%, 82 frequencies) and the action of carrying the food of the chelae $(1.55 \%, 65$ frequencies) were the predominant activities. At $2 \mathrm{~h}$, there was an increase in the movement activity in the LT $(31.87 \%, 634$ frequencies) concerning the ST $(30.66 \%, 610$ frequencies) and control treatment $(2.09 \%, 416$ frequencies). In the LT, the movement of the left and right maxillipeds when ingesting the food $(16.89 \%, 336$ frequencies), the action of carrying the food with the left chela $(6.28 \%$, 131 frequencies), and feeding (4.97\%, 99 frequencies), recorded greater activities.

At $24 \mathrm{~h}$, fewer repetitions were recorded in the treatments with regards to $2 \mathrm{~h}$, in the control treatment ST $(2.16 \%, 43$ frequencies), (1.35\%, 27 frequencies), and $\operatorname{LT}(1.30 \%, 26$ frequencies), while the movement of the right and left chelae and feeding were not registered (Fig. 1). There were no significant differences between treatments over the time of observation $(P>0.05)$ (Table 2).

\section{Movement}

The activity of the subgroups was observed after ablation respecting the movement of crabs. At $10 \mathrm{~min}$, ST (5.44\%, 14 frequencies) showed higher frequencies concerning the control treatment $(2.72 \%$, seven frequencies) and to LT (1.55\%, four frequencies). In the ST, the movement towards the front and back of the tank $(3.89 \%, 10$ frequencies) and swimming $(1.16 \%$, three frequencies) showed greater activity at $0 \mathrm{~h}$. During the $2 \mathrm{~h}$ period, the highest activity was observed in the ST with (34\%, 88 frequencies) in relation with the control treatment $(27.62 \%, 71$ frequencies) and LT with $(24.12 \%, 62$ frequencies). Under the ST, swimming $(16.73 \%, 43$ frequencies) and circular movement through the tank $(8.94 \%, 23$ frequencies) showed maximum activity.

At $24 \mathrm{~h}$, the number of repetitions of frequencies decreased in ST (2.38\%, two frequencies), LT (2.33\%, six frequencies), as well as in the control treatment (1.16\%, three frequencies), while no activity was obser- 
Table 1. Types of behavior characterize the effect of unilateral eyestalk ablation in breeders of the blue crab Callinectes arcuatus under laboratory conditions.

\begin{tabular}{|c|c|c|c|c|c|}
\hline $\begin{array}{l}\text { Behavioral } \\
\text { groups }\end{array}$ & Characteristics & $\begin{array}{l}\text { Time for } \\
\text { analysis }\end{array}$ & Activity & Statistic & $\begin{array}{c}\text { Level of } \\
\text { significance }\end{array}$ \\
\hline \multirow{3}{*}{ Feeding } & Maxillipeds & $\begin{array}{l}10 \mathrm{~min} \\
2 \mathrm{~h} \\
24 \mathrm{~h}\end{array}$ & Movement of maxillipeds & $\begin{array}{l}\text { Kruskal- Wallis, then } \\
\text { Mann- Whitney U Test }\end{array}$ & $P<0.05$ \\
\hline & $\begin{array}{l}\text { Right and left } \\
\text { chelae }\end{array}$ & $\begin{array}{l}10 \mathrm{~min} \\
2 \mathrm{~h} \\
24 \mathrm{~h}\end{array}$ & $\begin{array}{l}\text { Rubbing of maxillipeds with one of the } \\
\text { chelae }\end{array}$ & $\begin{array}{l}\text { Kruskal- Wallis, then } \\
\text { Mann- Whitney U Test }\end{array}$ & $P<0.05$ \\
\hline & Feeding & $\begin{array}{l}10 \mathrm{~min} \\
2 \mathrm{~h} \\
24 \mathrm{~h}\end{array}$ & $\begin{array}{l}\text { Grab food with the chelae and direct it } \\
\text { towards the mouth and food intake }\end{array}$ & $\begin{array}{l}\text { Kruskal- Wallis, then } \\
\text { Mann- Whitney U Test }\end{array}$ & $P<0.05$ \\
\hline \multirow{4}{*}{ Movement } & Back and forth & $\begin{array}{l}10 \mathrm{~min} \\
2 \mathrm{~h} \\
24 \mathrm{~h}\end{array}$ & $\begin{array}{l}\text { Crab travel around the vat forwards } \\
\text { and backward }\end{array}$ & $\begin{array}{l}\text { Kruskal- Wallis, then } \\
\text { Mann- Whitney U Test }\end{array}$ & $P<0.05$ \\
\hline & $\begin{array}{l}\text { Swimming } \\
\text { ("normal") }\end{array}$ & $\begin{array}{l}10 \mathrm{~min} \\
2 \mathrm{~h} \\
24 \mathrm{~h}\end{array}$ & $\begin{array}{l}\text { Moving through the water with natural } \\
\text { movements of the pleopods, without } \\
\text { touching the bottom of the vat }\end{array}$ & $\begin{array}{l}\text { Kruskal- Wallis, then } \\
\text { Mann- Whitney U Test }\end{array}$ & $P<0.05$ \\
\hline & $\begin{array}{l}\text { Swimming } \\
\text { upwards }\end{array}$ & $\begin{array}{l}10 \mathrm{~min} \\
2 \mathrm{~h} \\
24 \mathrm{~h}\end{array}$ & $\begin{array}{l}\text { Moving through the water with natural } \\
\text { movements of the pleopods, across the } \\
\text { water column, towards the vat's surface }\end{array}$ & $\begin{array}{l}\text { Kruskal- Wallis, then } \\
\text { Mann- Whitney U Test }\end{array}$ & $P<0.05$ \\
\hline & $\begin{array}{l}\text { Swimming in a } \\
\text { circular motion }\end{array}$ & $\begin{array}{l}10 \mathrm{~min} \\
2 \mathrm{~h} \\
24 \mathrm{~h}\end{array}$ & $\begin{array}{l}\text { Moving through the water with natural } \\
\text { movements of pleopods, peripherally } \\
\text { along the vat }\end{array}$ & $\begin{array}{l}\text { Kruskal- Wallis, then } \\
\text { Mann- Whitney U Test }\end{array}$ & $P<0.05$ \\
\hline \multirow{5}{*}{ Disorientation } & Zig-zag & $\begin{array}{l}10 \mathrm{~min} \\
2 \mathrm{~h} \\
24 \mathrm{~h}\end{array}$ & $\begin{array}{l}\text { Erratic movement of the crab from side } \\
\text { to side in the vat }\end{array}$ & $\begin{array}{l}\text { Kruskal- Wallis, then } \\
\text { Mann- Whitney U Test }\end{array}$ & $P<0.05$ \\
\hline & Twist on its axis & $\begin{array}{l}10 \mathrm{~min} \\
2 \mathrm{~h} \\
24 \mathrm{~h}\end{array}$ & $\begin{array}{l}\text { Erratic movement of the crab on its } \\
\text { axis }\end{array}$ & $\begin{array}{l}\text { Kruskal- Wallis, then } \\
\text { Mann- Whitney U Test }\end{array}$ & $P<0.05$ \\
\hline & $\begin{array}{l}\text { Circular } \\
\text { movement of } \\
\text { the swimming } \\
\text { appendage }\end{array}$ & $\begin{array}{l}10 \mathrm{~min} \\
2 \mathrm{~h} \\
24 \mathrm{~h}\end{array}$ & $\begin{array}{l}\text { Erratic movement of the swimming } \\
\text { appendages in a circular manner }\end{array}$ & $\begin{array}{l}\text { Kruskal- Wallis, then } \\
\text { Mann- Whitney U Test }\end{array}$ & $P<0.05$ \\
\hline & $\begin{array}{l}\text { Movement of } \\
\text { swimming } \\
\text { appendages }\end{array}$ & $\begin{array}{l}10 \mathrm{~min} \\
2 \mathrm{~h} \\
24 \mathrm{~h}\end{array}$ & $\begin{array}{l}\text { Erratic movement of swimming } \\
\text { appendages up and down in a constant } \\
\text { manner }\end{array}$ & $\begin{array}{l}\text { Kruskal- Wallis, then } \\
\text { Mann- Whitney U Test }\end{array}$ & $P<0.05$ \\
\hline & $\begin{array}{l}\text { Retraction in the } \\
\text { vat }\end{array}$ & $\begin{array}{l}10 \mathrm{~min} \\
2 \mathrm{~h} \\
24 \mathrm{~h}\end{array}$ & $\begin{array}{l}\text { Erratic movement of the crab when } \\
\text { sticking to the walls of the vat }\end{array}$ & $\begin{array}{l}\text { Kruskal- Wallis, then } \\
\text { Mann- Whitney U Test }\end{array}$ & $P<0.05$ \\
\hline \multirow{3}{*}{ Inactivity } & Resting & $\begin{array}{l}0 \mathrm{~h} \\
2 \mathrm{~h} \\
24 \mathrm{~h}\end{array}$ & $\begin{array}{l}\text { Staying in the vat without making a } \\
\text { move }\end{array}$ & $\begin{array}{l}\text { Kruskal- Wallis, then } \\
\text { Mann- Whitney U Test }\end{array}$ & $P<0.05$ \\
\hline & Refuge & $\begin{array}{l}0 \mathrm{~h} \\
2 \mathrm{~h} \\
24 \mathrm{~h}\end{array}$ & Staying in shelters without moving & $\begin{array}{l}\text { Kruskal- Wallis, then } \\
\text { Mann- Whitney U Test }\end{array}$ & $P<0.05$ \\
\hline & $\begin{array}{l}\text { Approach to air } \\
\text { diffuser stones }\end{array}$ & $\begin{array}{l}0 \mathrm{~h} \\
2 \mathrm{~h} \\
24 \mathrm{~h}\end{array}$ & $\begin{array}{l}\text { Staying close to the air diffuser stones } \\
\text { without moving }\end{array}$ & $\begin{array}{l}\text { Kruskal- Wallis, then } \\
\text { Mann- Whitney U Test }\end{array}$ & $P<0.05$ \\
\hline \multirow{5}{*}{ Aggressiveness } & Scale 0 & $\begin{array}{l}10 \mathrm{~min} \\
2 \mathrm{~h} \\
24 \mathrm{~h}\end{array}$ & $\begin{array}{l}\text { Confrontation among crabs without } \\
\text { touching each other }\end{array}$ & $\chi^{2}$ & $P<0.05$ \\
\hline & Scale 1 & $\begin{array}{l}10 \mathrm{~min} \\
2 \mathrm{~h} \\
24 \mathrm{~h}\end{array}$ & $\begin{array}{l}\text { Prickling among crabs and chelae } \\
\text { releasing }\end{array}$ & $\chi^{2}$ & $P<0.05$ \\
\hline & Scale 2 & $\begin{array}{l}10 \mathrm{~min} \\
2 \mathrm{~h} \\
24 \mathrm{~h}\end{array}$ & Subjection for a short period & $\chi^{2}$ & $P<0.05$ \\
\hline & Scale 3 & $\begin{array}{l}10 \mathrm{~min} \\
2 \mathrm{~h} \\
24 \mathrm{~h}\end{array}$ & Mutilation of the body part of a crab & $\chi^{2}$ & $P<0.05$ \\
\hline & Scale 4 & $\begin{array}{l}10 \mathrm{~min} \\
2 \mathrm{~h} \\
24 \mathrm{~h}\end{array}$ & Death of a crab by confrontation & $\chi^{2}$ & $P<0.05$ \\
\hline
\end{tabular}




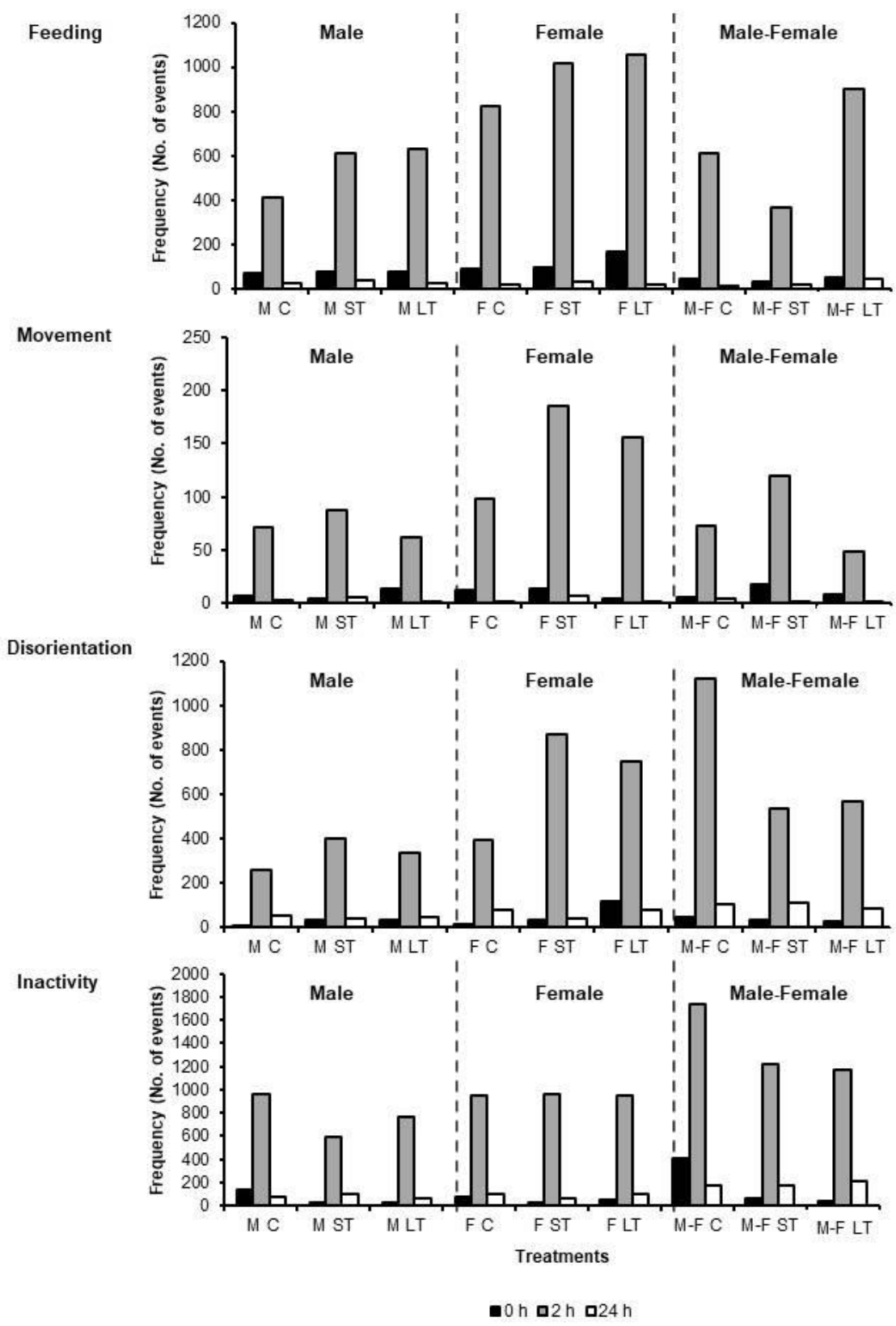

Figure 1. Activities that characterize the behavior of crab breeders of Callinectes arcuatus under laboratory conditions. MC: male control, MST: male squash treatment, MLT: male ligation treatment, FC: female control, FST: female squash treatment, FLT: female ligation treatment, M-FC: male-female control, M-F ST: male-female squash treatment, M-F LT: male-female ligation treatment.

ved in walking forward, backward, and on those crabs displaying a circular path around the periphery of the tank (Fig. 1). There were no significant differences between treatments through the duration of the experiment $(P>0.05)$ (Table 2$)$.

\section{Disorientation}

Concerning the disorientation group in males, the activity of the subgroups after the ablation treatments were recorded. At 10 min the control group $(0.82 \%, 10$ frequencies) showed less activity in relation to the types of ablations, ST $(2.71 \%, 33$ frequencies) and LT (2.96\%, 36 frequencies). The movement of the swimming limbs $(1.40 \%, 17$ frequencies) showed greater activity about the types of ablations. The greatest disorientation of crabs occurred at $2 \mathrm{~h}$ under the ST $(33.08 \%, 402$ frequencies); they were pulling back to the walls of the tank $(13.50 \%, 164$ frequencies $)$, 
Table 2. Evaluation of the effect of unilateral eyestalk ablation on the behavior of breeders of the crab Callinectes arcuatus under laboratory conditions. C: control, ST: squash ablation treatment, LT: ligation ablation treatment. Significant differences are in bold $(P<0.05)$.

\begin{tabular}{|c|c|c|c|c|c|c|c|}
\hline $\begin{array}{l}\text { Behavior } \\
\text { (groups) }\end{array}$ & Sex biossay & $\begin{array}{l}\text { Time for analysis } \\
\text { (h) }\end{array}$ & Treatments & Frequencies & $\begin{array}{c}\mathrm{K}-\mathrm{W}, \mathrm{H} \text { Test } \\
(2, \mathrm{n}=54)\end{array}$ & Probability & $\begin{array}{c}\text { Significance } \\
\alpha=0.05\end{array}$ \\
\hline \multirow{27}{*}{ Feeding } & \multirow[t]{9}{*}{ Females } & \multirow{3}{*}{$10 \mathrm{~min}$} & Control & 92 & \multirow{3}{*}{4.1882} & \multirow{3}{*}{0.1232} & \multirow{3}{*}{$P>0.05$} \\
\hline & & & ST & 99 & & & \\
\hline & & & LT & 167 & & & \\
\hline & & \multirow{3}{*}{2} & Control & 826 & \multirow{3}{*}{1.0939} & \multirow{3}{*}{0.5787} & \multirow{3}{*}{$P>0.05$} \\
\hline & & & ST & 1057 & & & \\
\hline & & & LT & 1019 & & & \\
\hline & & \multirow{3}{*}{24} & Control & 24 & \multirow{3}{*}{2.9446} & \multirow{3}{*}{0.2294} & \multirow{3}{*}{$P>0.05$} \\
\hline & & & $\mathrm{ST}$ & 33 & & & \\
\hline & & & LT & 24 & & & \\
\hline & \multirow[t]{9}{*}{ Males } & \multirow{3}{*}{$10 \mathrm{~min}$} & Control & 75 & \multirow{3}{*}{1.9303} & \multirow{3}{*}{0.3809} & \\
\hline & & & $\mathrm{ST}$ & 78 & & & $P>0.05$ \\
\hline & & & LT & 80 & & & \\
\hline & & & Control & 416 & & & \\
\hline & & 2 & ST & 610 & 5.4237 & 0.0664 & $P>0.05$ \\
\hline & & & LT & 634 & & & \\
\hline & & & Control & 27 & & & \\
\hline & & 24 & ST & 43 & 0.3135 & 0.8549 & $P>0.05$ \\
\hline & & & $\mathrm{LT}$ & 26 & & & \\
\hline & Both & & Control & 46 & & & \\
\hline & & $10 \mathrm{~min}$ & ST & 32 & 2.621 & 0.2697 & $P>0.05$ \\
\hline & & & LT & 53 & & & \\
\hline & & & Control & 613 & & & \\
\hline & & 2 & ST & 369 & 7.956 & 0.0187 & $P<0.05$ \\
\hline & & & LT & 900 & & & \\
\hline & & & Control & 16 & & & \\
\hline & & 24 & ST & 20 & 4.1701 & 0.1243 & $P>0.05$ \\
\hline & & & LT & 44 & & & \\
\hline & Females & & Control & 12 & & & \\
\hline & & $10 \mathrm{~min}$ & ST & 14 & 1.7757 & 0.4116 & $P>0.05$ \\
\hline & & & LT & 4 & & & \\
\hline & & & Control & 88 & & & \\
\hline & & 2 & ST & 185 & 0.3834 & 0.8257 & $P>0.05$ \\
\hline & & & LT & 156 & & & \\
\hline & & & Control & 2 & & & \\
\hline & & 24 & ST & 7 & 0.8814 & 0.6436 & $P>0.05$ \\
\hline & & & LT & 2 & & & \\
\hline & Males & & Control & 7 & & & \\
\hline & & $10 \mathrm{~min}$ & ST & 4 & 1.298 & 0.5226 & $P>0.05$ \\
\hline & & & LT & 14 & & & \\
\hline Movement & & & Control & 71 & & & \\
\hline & & 2 & $\mathrm{ST}$ & 88 & 2.8582 & 0.2395 & $P>0.05$ \\
\hline & & & LT & 62 & & & \\
\hline & & & Control & 3 & & & \\
\hline & & 24 & ST & 6 & 1.8883 & 0.389 & $P>0.05$ \\
\hline & & & LT & 2 & & & \\
\hline & Both & & Control & 6 & & & \\
\hline & & $10 \mathrm{~min}$ & $\mathrm{ST}$ & 18 & 2.0887 & 0.3519 & $P>0.05$ \\
\hline & & & LT & 9 & & & \\
\hline & & & Control & 73 & & & \\
\hline & & 2 & ST & 120 & 3.393 & 0.1833 & $P>0.05$ \\
\hline & & & LT & 49 & & & \\
\hline & & & Control & 4 & & & \\
\hline & & 24 & ST & 1 & 0.1532 & 0.9262 & $P>0.05$ \\
\hline & & & LT & 2 & & & \\
\hline
\end{tabular}


Continuation

\begin{tabular}{|c|c|c|c|c|c|c|c|}
\hline $\begin{array}{l}\text { Behavior } \\
\text { (groups) }\end{array}$ & Sex biossay & $\begin{array}{l}\text { Time for analysis } \\
\text { (h) }\end{array}$ & Treatments & Frequencies & $\begin{array}{c}\mathrm{K}-\mathrm{W}, \mathrm{H} \text { Test } \\
(2, \mathrm{n}=54)\end{array}$ & Probability & $\begin{array}{c}\text { Significance } \\
\alpha=0.05\end{array}$ \\
\hline \multirow{27}{*}{ Disorientation } & \multirow[t]{9}{*}{ Females } & \multirow{3}{*}{$10 \mathrm{~min}$} & Control & 13 & \multirow{3}{*}{3.7428} & \multirow{3}{*}{0.1539} & \multirow{3}{*}{$P>0.05$} \\
\hline & & & ST & 34 & & & \\
\hline & & & LT & 116 & & & \\
\hline & & \multirow{3}{*}{2} & Control & 397 & \multirow{3}{*}{1.9979} & \multirow{3}{*}{0.3683} & \multirow{3}{*}{$P>0.05$} \\
\hline & & & ST & 869 & & & \\
\hline & & & $\mathrm{LT}$ & 749 & & & \\
\hline & & \multirow{3}{*}{24} & Control & 78 & \multirow{3}{*}{0.1138} & \multirow{3}{*}{0.9447} & \multirow{3}{*}{$P>0.05$} \\
\hline & & & ST & 42 & & & \\
\hline & & & LT & 81 & & & \\
\hline & Male & \multirow{3}{*}{$10 \mathrm{~min}$} & Control & 10 & \multirow{3}{*}{4.6054} & \multirow{3}{*}{0.0999} & \multirow{3}{*}{$P>0.05$} \\
\hline & & & ST & 33 & & & \\
\hline & & & LT & 36 & & & \\
\hline & & & Control & 260 & & & \\
\hline & & 2 & $\mathrm{ST}$ & 402 & 9.1098 & 0.0105 & $P<0.05$ \\
\hline & & & LT & 336 & & & \\
\hline & & & Control & 51 & & & \\
\hline & & 24 & ST & 40 & 0.2071 & 0.9016 & $P>0.05$ \\
\hline & & & LT & 47 & & & \\
\hline & Both & & Control & 49 & & & \\
\hline & & $10 \mathrm{~min}$ & ST & 33 & 0.4614 & 0.794 & $P>0.05$ \\
\hline & & & LT & 26 & & & \\
\hline & & & Control & 1121 & & & \\
\hline & & 2 & ST & 534 & 4.177 & 0.1239 & $P>0.05$ \\
\hline & & & LT & 569 & & & \\
\hline & & & Control & 103 & & & \\
\hline & & 24 & $\mathrm{ST}$ & 113 & 3.3461 & 0.1877 & $P>0.05$ \\
\hline & & & LT & 85 & & & \\
\hline & Females & & Control & 76 & & & \\
\hline & & $10 \mathrm{~min}$ & ST & 24 & 3.0644 & 0.2161 & $P>0.05$ \\
\hline & & & LT & 50 & & & \\
\hline & & & Control & 949 & & & \\
\hline & & 2 & ST & 965 & 0.1305 & 0.9368 & $P>0.05$ \\
\hline & & & LT & 944 & & & \\
\hline & & & Control & 101 & & & \\
\hline & & 24 & ST & 70 & 0.1543 & 0.9257 & $P>0.05$ \\
\hline & & & LT & 98 & & & \\
\hline & Males & & Control & 132 & & & \\
\hline & & $10 \mathrm{~min}$ & ST & 27 & 0.445 & 0.7965 & $P>0.05$ \\
\hline & & & LT & 28 & & & \\
\hline & & & Control & 965 & & & \\
\hline Inactivity & & 2 & $\mathrm{ST}$ & 588 & 1.7046 & 0.4264 & $P>0.05$ \\
\hline & & & LT & 762 & & & \\
\hline & & & Control & 82 & & & \\
\hline & & 24 & ST & 104 & 1.082 & 0.5822 & $P>0.05$ \\
\hline & & & LT & 64 & & & \\
\hline & Both & & Control & 405 & & & \\
\hline & & $10 \mathrm{~min}$ & ST & 61 & 1.7804 & 0.4106 & $P>0.05$ \\
\hline & & & LT & 42 & & & \\
\hline & & & Control & 1736 & & & \\
\hline & & 2 & ST & 1215 & 0.276 & 0.8711 & $P>0.05$ \\
\hline & & & LT & 1168 & & & \\
\hline & & & Control & 171 & & & \\
\hline & & 24 & ST & 175 & 0.9374 & 0.6258 & $P>0.05$ \\
\hline & & & $\mathrm{LT}$ & 209 & & & \\
\hline
\end{tabular}

and the agitation of the swimming appendages (8.15\%, 99 frequencies) were the actions with the highest number of repetitions, concerning LT $(27.64 \%, 336$ frequencies) and the control treatment $(21.39 \%, 260$ frequencies). 
At $24 \mathrm{~h}$, control activities of the control treatment were reduced $4.19 \%$ (51 frequencies), as well as in the LT 3.88\% (47 frequencies) and ST 3.29\% (40 frequencies), did not show the activity of spinning and agitation of their swimming limbs (Fig. 1). There were significant differences between treatments at $2 \mathrm{~h}$ $(P<0.05)$ (Table 2).

\section{Inactivity}

The principal activity in the control treatment was resting (Fig. 1). In the inactivity group, after having performed the ablations to the organisms, strong inactivity at $0 \mathrm{~h}$ was seen in the control treatment (4.79\%, 132 frequencies) concerning LT and $(1.01 \%$, 28 frequencies) ST $(0.98 \%, 27$ frequencies). The greatest resting period was recorded at $2 \mathrm{~h}$ in the control treatment $(35.06 \%, 965$ frequencies), unlike the LT (27.69\%, 762 frequencies) and the ST $(21.37 \%, 588$ frequencies), being the control treatment one that showed the highest number of repetitions $(33.36 \%, 918$ frequencies). At $24 \mathrm{~h}$, there was a decrease in the actions in the treatments in which ST $(3.77 \%, 104$ frequencies) was the most active concerning the control treatment $(2.97 \%, 82$ frequencies) and LT $(2.32 \%, 64$ frequencies). No significant differences between treatments through the duration of the experiment were recorded $(P>0.05)$ (Table 2).

\section{Aggressiveness}

For males, in the aggressiveness group, at $10 \mathrm{~min}$, there was a little response after the ablations. In the aggressiveness scale A0 (confrontation of the crabs without touching each other), the control showed a greater clash among the crabs $(1.62 \%$, six frequencies) relating to ST and LT (1.35\%, five frequencies), which were similar. The A1 level (crabs pricking each other and release of the chelae) was only seen within the control treatment $(2.16 \%$, eight frequencies) and LT ( $1.08 \%$, four frequencies) in contrast to ST, where no hostility was presented among organisms. No activity was recorded in the treatments for other levels of aggressiveness like A2 (subjection for a short period), A3 (mutilation of a body part of the crab), and A4 (death of an individual due to confrontation) (Fig. 1, Table 3).

The maximum rivalry in males was observed at $2 \mathrm{~h}$ as it is explained: $\mathrm{A} 0(\mathrm{C}=20.32 \%, 75$ frequencies; $\mathrm{ST}$ $=9.75 \%, 36$ frequencies; and $\mathrm{LT}=18.69 \%, 69$ frequencies), where males showed a greater response for $\mathrm{A} 1(\mathrm{C}=11.38 \%, 42$ frequencies; $\mathrm{ST}=16.26 \%, 60$ frequencies; $\mathrm{LT}=8.40 \%, 31$ frequencies), and a decrease in $\mathrm{A} 2(\mathrm{C}=0 \%, 0$ frequencies; $\mathrm{ST}=1.89 \%$, seven frequencies; $\mathrm{LT}=1.62 \%$, six frequencies), $\mathrm{A} 3$ (C $=0 \%, 0$ frequencies; $\mathrm{ST}=0 \%, 0$ frequencies; $\mathrm{LT}=$
$0.27 \%$, one frequency) and $\mathrm{A} 4(\mathrm{C}=0 \%, 0$ frequencies; $\mathrm{ST}=0.27 \%$, one frequency; $\mathrm{LT}=0 \%, 0$ frequencies) (Table 3).

The aggression among males showed a low intensity in the treatments at $24 \mathrm{~h}$, where only A0 aggressiveness was recorded with the same values in the control and LT $(0.54 \%$, two frequencies), whereas the ST registered it with $1.08 \%$ (four frequencies). For the A1 level, the control treatment and the ST had the same response of aggression with $0.54 \%$ (two frequencies), while in the LT, it was less with $0.21 \%$ (one frequency). No activity was recorded for A2, A3, and A4 levels of aggressiveness, and there were significant differences among treatments in $2 \mathrm{~h}$ time, showing more greater activity (53\%, 75 frequencies) in the control treatment in the scale A0 (confrontation among crabs without touching each other) $(P<0.05)$ (Table 3).

\section{Bioassay in females of $C$. arcuatus Feeding}

Feeding (group) in females showed an increase in the activity of the subgroups after ablation (Table 2). At 10 min, both the control treatment and the ST showed a similar number of actions carried out by the organisms $(\mathrm{C}=2.75 \%, \mathrm{ST}=2.96 \%$, respectively), whereas the individuals under the LT were more active with $4.99 \%$ (167 frequencies), where the movement of the oral left and right maxillipeds used by the crab to ingest food was the predominant activity. At $2 \mathrm{~h}$, there was a greater activity of movements in the LT $(31.637 \%, 1057$ frequencies) and the ST (30.49\%, 1090 frequencies) concerning the control treatment $(24.72 \%, 826$ frequencies). The left and right maxillipeds movement after ingesting food under the $\mathrm{LT}$ registered the highest activity (25.09\%, 838 frequencies). At $24 \mathrm{~h}$, the control treatment and the LT with $0.71 \%$ (24 frequencies) showed a decrease in the movements $1.35 \%$ (27 frequencies), the movement of the left maxilliped, and the movement of the left chela, while in the feeding activity no actions were observed. On the other hand, with the ablation by ST with $0.98 \%$ (33 frequencies), all the activities were registered (Fig. 1). There were no significant differences in males-females at $2 \mathrm{~h}(P>$ 0.05) (Table 2).

\section{Movement}

Activities were recorded within the movement (group) of crabs after ablation. At $10 \mathrm{~min}$, the control treatment $(2.5 \%, 12$ frequencies) and the ST $(2.91 \%, 14$ frequencies) showed an increase in the actions concerning the LT $(0.83 \%$, four frequencies), which presented a decrease in the movements. At $2 \mathrm{~h}$, the activity intensified under the ST with 38\% (185 frequen- 
Table 3. Aggressive behavior of males, females, and male-females of the crab Callinectes arcuatus under laboratory conditions. C: control, ST: squash ablation treatment, LT: ligation ablation treatment. Significant differences are in bold $(P<0.05)$.

\begin{tabular}{|c|c|c|c|c|c|c|c|c|}
\hline $\begin{array}{l}\text { Behavior } \\
\text { (groups) }\end{array}$ & $\begin{array}{c}\text { Sex } \\
\text { Bioassay }\end{array}$ & $\begin{array}{l}\text { Time for } \\
\text { analysis } \\
\text { (h) }\end{array}$ & Treatments & $\begin{array}{l}\text { Aggressive } \\
\text { scale }\end{array}$ & $\begin{array}{c}\text { Significance by } \\
\text { aggressiveness scale }\end{array}$ & $\begin{array}{l}X^{2} \text { pool test } \\
(2, \mathrm{n}=54)\end{array}$ & $\begin{array}{l}X^{2} \text { Critical } \\
(\alpha, n=54)\end{array}$ & $\begin{array}{c}\text { Significance } \\
\alpha=0.05\end{array}$ \\
\hline & Males & T0 (10 min) & Control & 0 & 10.1333 & 26.5778 & 30.612 & $P>0.05$ \\
\hline & & & ST & 1 & 16.4444 & & & \\
\hline & & & LT & 2 & - & & & \\
\hline & & & & 3 & - & & & \\
\hline & & & & 4 & - & & & \\
\hline & & $\mathrm{T} 2$ & Control & 0 & 11.9735 & 104.1034 & 30.612 & $P<0.05$ \\
\hline & & & ST & 1 & 37.0062 & & & \\
\hline & & & $\mathrm{LT}$ & 2 & 15.0309 & & & \\
\hline & & & & 3 & 2.0654 & & & \\
\hline & & & & 4 & 2.1538 & & & \\
\hline & & $\mathrm{T} 24$ & Control & 0 & 2.8333 & 7.9444 & 30.612 & $P>0.05$ \\
\hline & & & ST & 1 & 5.1111 & & & \\
\hline & & & LT & 2 & - & & & \\
\hline & & & & 3 & - & & & \\
\hline & & & & 4 & - & & & \\
\hline & Females & T0 (10 min) & Control & 0 & 13.2083 & 43.7138 & 30.612 & $P<0.05$ \\
\hline & & & ST & 1 & 9.5054 & & & \\
\hline & & & LT & 2 & - & & & \\
\hline & & & & 3 & - & & & \\
\hline & & & & 4 & 21.0 & & & \\
\hline & & $\mathrm{T} 2$ & Control & 0 & 95.9816 & 156.1234 & 30.612 & $P<0.05$ \\
\hline & & & ST & 1 & 49.4610 & & & \\
\hline \multirow[t]{23}{*}{ Aggressive } & & & $\mathrm{LT}$ & 2 & 8.0074 & & & \\
\hline & & & & 3 & - & & & \\
\hline & & & & 4 & 2.6734 & & & \\
\hline & & $\mathrm{T} 24$ & Control & 0 & - & 9.0 & 30.612 & $P>0.05$ \\
\hline & & & ST & 1 & 9.0 & & & \\
\hline & & & LT & 2 & - & & & \\
\hline & & & & 3 & - & & & \\
\hline & & & & 4 & - & & & \\
\hline & Both & T0 (10 min) & Control & 0 & 8.7429 & 12.0839 & 30.612 & $P>0.05$ \\
\hline & & & ST & 1 & 2.3886 & & & \\
\hline & & & $\mathrm{LT}$ & 2 & 0.9524 & & & \\
\hline & & & & 3 & - & & & \\
\hline & & & & 4 & - & & & \\
\hline & & $\mathrm{T} 2$ & Control & 0 & 13.5307 & 63.8570 & 30.612 & $P<0.05$ \\
\hline & & & ST & 1 & 38.0886 & & & \\
\hline & & & $\mathrm{LT}$ & 2 & 12.2377 & & & \\
\hline & & & & 3 & - & & & \\
\hline & & & & 4 & - & & & \\
\hline & & $\mathrm{T} 24$ & Control & 0 & - & 15.0 & 30.612 & $P>0.05$ \\
\hline & & & ST & 1 & 11.3636 & & & \\
\hline & & & LT & 2 & 7.2727 & & & \\
\hline & & & & 3 & - & & & \\
\hline & & & & 4 & - & & & \\
\hline
\end{tabular}

cies) and the LT with $32.5 \%$ (156 frequencies), being the swimming subgroup $(29.79 \%, 143$ frequencies) the one with the highest activity in each treatment, while the control treatment showed a $20.41 \%$ (98 frequencies). The upward swimming subgroup $(9.58 \%, 46$ fre- quencies) and the forward swimming subgroup (5.63\%, 27 frequencies) were the ones that displayed the most frequent activities. At $24 \mathrm{~h}$, there was a strong decrease in the number of repetitions in the subgroups, in the ST ( $1.48 \%$, seven frequencies), the LT $(0.41 \%$, two fre- 
quencies), and in the control treatment $(1.16 \%$, three frequencies), where the only activity seen was upward swimming in the three treatments (Fig. 1). There were no significant differences among the treatments throughout the experiment $(P>0.05)$ (Table 2).

\section{Disorientation}

Concerning the group of disoriented females, activity was recorded in those subgroups under treatments before ablation. At $10 \mathrm{~min}$, the control treatment $(0.54 \%, 13$ frequencies) showed less activity in relation to the LT $(4.87 \%, 116$ frequencies) and the ST $(1.49 \%$, 34 frequencies). The greatest disorientation of females occurred at $2 \mathrm{~h}$ after the ST (36.08\%, 869 frequencies), where retraction towards the walls of the vat $(24.12 \%$, 574 frequencies) was the action with the highest number of repetitions, concerning the LT $(31.48 \%, 749$ frequencies) and the control treatment $(16.68 \%, 397$ frequencies). At $24 \mathrm{~h}$, activities were reduced, being similar to the ones displayed in the control treatment $3.27 \%$ (78 frequencies) and the LT $3.40 \%$ (81 frequencies), concerning the ST $1.76 \%$ (42 frequencies), where the actions displayed by crabs were rotation in their axis and retraction towards the wall of the tank (Fig. 1). There were no significant differences among the treatments used in the experiment $(P>0.05)$ (Table 2).

\section{Inactivity}

In the group that showed inactivity, the crabs rested after suffering the ablations. At $0 \mathrm{~h}$, there was a clear tendency of the organisms to be at rest in the control treatment $(2.31 \%, 76$ frequencies), concerning the LT $(1.52 \%, 50$ frequencies) and the ST $(0.73 \%, 24$ frequencies). In the control treatment, resting was the principal activity $(1.61 \%, 53$ frequencies). At $2 \mathrm{~h}$, there was greater immobility in those crabs under ST (29.44\%, 965 frequencies), the control treatment (28.95\%, 949 frequencies), and the LT $(28.80 \%, 944$ frequencies), where resting $17.48 \%$ (573 frequencies) was the main activity performed by females in ST. After $24 \mathrm{~h}$, a decrease in the inactivity of the organisms was observed, being the control treatment $(3.08 \%, 101$ frequencies) the most passive one concerning the LT (2.99\%, 98 frequencies) and the ST $(2.13 \%, 70$ frequencies), while the resting action occurred in the three treatments (Fig. 1). There were no significant differences among treatments through the duration of the experiment $(P>0.05)$ (Table 2$)$.

\section{Aggressiveness}

In females, the group of aggressiveness at $10 \mathrm{~min}$ presented little response after ablations. In the aggressiveness scale A0 (crab confrontation without touching each other), the LT showed a higher provocation $(2.80 \%, 15$ frequencies) concerning the control treatment $(0.37 \%$, eight frequencies) and the ST, where there was no aggression at all. There was no type of aggressiveness A2 (subjection for a shorter period) recorded in the treatments. The LT $(3.18 \%, 17$ frequencies) showed the highest action displaying A1 level of aggressiveness (pricking among crabs and the release of chelae) when compared to the ST $(1.93 \%$, four frequencies) and the control treatment $(1.49 \%$, eight frequencies).

The highest aggression among females was seen at $2 \mathrm{~h}$ as follows: $\mathrm{A} 0(\mathrm{C}=7.11 \%, 38$ frequencies; $\mathrm{ST}=$ $6.17 \%, 33$ frequencies; $\mathrm{LT}=7.11 \%, 38$ frequencies), with a higher response from the crabs to A1 $(\mathrm{C}=$ $11.42 \%, 61$ frequencies; ST $=29.96 \%, 160$ frequencies; $\mathrm{LT}=23.97 \%, 128$ frequencies), and lower one to A2 $(\mathrm{C}=1.68 \%$, nine frequencies; $\mathrm{ST}=1.93 \%$, four frequencies; $\mathrm{LT}=2.83 \%$, six frequencies).

Aggressiveness among females decreased in intensity in the treatments after $24 \mathrm{~h}$, where A1 type aggressiveness was recorded in the ST $(0.74 \%$, four frequencies) and LT ( $0.93 \%$, five frequencies), whereas the control treatment did not register any sign of aggressiveness among individuals (Fig. 1). There were significant differences among treatments throughout the experiment. In the LT treatment at $0 \mathrm{~h}$, the scales A0 $(2.80 \%, 15$ frequencies) and A1 $(3.18 \%, 17$ frequencies) showed the greatest aggressiveness activity in the organisms. $(P<0.05)$ (Table 3$)$.

\section{Bioassay male-females of $C$. arcuatus Feeding}

The male-females feeding bioassay group showed initial activities at $10 \mathrm{~min}$ in those subgroups that had undergone ablation, the LT $(2.53 \%, 53$ frequencies) and the control group $(2.19 \%, 46$ frequencies), while the crabs that were in the ST were less active with $1.58 \%$ (32 frequencies). In the LT treatment, the right and left oral maxillipeds agitation $(1.62 \%, 35$ frequencies) showed the highest activity. At $2 \mathrm{~h}$, more movements were recorded in the LT $(43.0 \%, 900$ frequencies) and control treatment $(29.28 \%, 613$ frequencies) concerning the ST $(17.63 \%, 369$ frequencies). In the LT, the movement of oral maxillipeds while ingesting food (19.23\%, 413 frequencies) and the movement of the left chela $(7.64 \%, 160$ frequencies) showed higher activity. At $24 \mathrm{~h}$, the treatments revealed a decrease in those activities where ablation by LT $2.10 \%$ (44 frequencies) was performed in comparison to the control treatment $(0.76 \%, 16$ frequencies) and ST $(0.95 \%, 20$ frequencies), producing a decrease in the movements of the right and left chela and during the feeding activity (Fig. 1). There 
were significant differences in the $2 \mathrm{~h}$ period among treatments through the experiment, showing the highest number of repetitions of the right and left oral maxillipeds $(1.67 \%, 35$ frequencies in the LT treatment) (Table 2).

\section{Movement}

The group that showed movement for both sexes revealed that the subgroups displayed activity after ablation. At 10 min, crabs that went ST exhibited higher amounts of activities (6.25\%, 18 frequencies) concerning the LT $(3.19 \%$, nine frequencies) and the control treatment $(2.12 \%$, six frequencies). In the ST treatment, swimming $(5.90 \%, 17$ frequencies) showed the greatest activity at $0 \mathrm{~h}$. After $2 \mathrm{~h}$, the activities intensified in those crabs under ST 42\% (120 frequencies), where most of the activities displayed in the tanks were the ones carried out by the subgroup of crabs that swam to the upper part of the vat $(19.81 \%$, 54 frequencies) and the subgroup that displayed normal swimming (13.82\%, 39 frequencies). The most common activities seen in the control treatment $25.34 \%$ (73 frequencies) were the subgroup of crabs that swam towards the front of the tank (13.54\%, 39 frequencies) and the subgroup that swam towards the back of the tank $(7.63 \%, 22$ frequencies). After $24 \mathrm{~h}$, there was a clear reduction in the number of repetitions in the subgroups, in the control treatment $(1.38 \%$, four frequencies), the LT $(0.71 \%$, two frequencies) and the ST $(0.35 \%$, one frequency), as the only activity recorded was swimming to the top part of the vat in the three treatments (Fig. 1). There were no significant differences among treatments through the experiment $(P>0.05)$ (Table 2$)$.

\section{Disorientation}

Concerning the disoriented group of males/females, activity was recorded in the subgroups that underwent ablation. At $10 \mathrm{~min}$ the $\mathrm{LT}(0.98 \%, 26$ frequencies) showed less activity concerning the ST $(1.25 \%, 33$ frequencies) and the control treatment (1.86\%, 49 frequencies). Retreating towards the tank's walls showed the highest number of repetitions.

The biggest disorientation in females was seen after $2 \mathrm{~h}$ in the control treatment (42.57\%, 1121 frequencies), where retracting to the walls of the tank $(41.77 \%, 1100$ frequencies) was the action with the highest number of repetitions, concerning the LT (21.61\%, 569 frequencies) and the ST (20.28\%, 534 frequencies).

At $24 \mathrm{~h}$, there was a decrease in the activities seen in the treatments, being similar for both the control treatment $3.91 \%$ (103 frequencies) and LT with 3.22\% (85 frequencies), concerning ST 4.29\% (113 frequencies). The activities displayed were the movement of the swimming appendages, the movement of the swimming appendages in a circular motion, and retraction within the tank (Fig. 1). No significant differences among the treatments were recorded through the experiment $(P>0.05)$ (Table 2).

\section{Inactivity}

In the male/females inactivity group, the crabs stopped moving after being subjected to ablation. At $10 \mathrm{~min}$, the control group showed $(7.81 \%, 405$ frequencies) a notorious resting stage concerning the LT $(0.81 \%, 42$ frequencies) and the ST (1.17\%, 61 frequencies). The greatest stillness was recorded after $2 \mathrm{~h}$ in the control treatment $(33.50 \%, 1735$ frequencies) in contrast to the ST $(23.44 \%, 1215$ frequencies) and LT $(22.53 \%, 1168$ frequencies), with rest showing the greatest number of repetitions (22.03\%, 1142 frequencies). At $24 \mathrm{~h}$, there was a decrease in the inactivity of crabs, where LT (4.03\%, 209 frequencies) was the one displaying more passiveness concerning ST (3.37\%, 175 frequencies), and the control treatment (3.29\%, 171 frequencies) (Fig. 1). There were no significant differences among the treatments during the experiment $(P>0.05)$ (Table 2).

\section{Aggressiveness}

The male-female aggressiveness group presented a small response after ablations at $10 \mathrm{~min}$. At the A0 level (crabs confronting each other without touching each other), the response was the same for the three treatments $(0.49 \%$, six frequencies). For A1 level (pricking among crabs and the release of chelae), the main action was seen in the ST $(1.84 \%, 13$ frequencies), unlike the control treatment $(0.56 \%$, four frequencies) and the ST $(0.14 \%$, one frequency). As for A2 (subjection for a short period), no activity was registered in the control treatment. However, the LT $(0.56 \%$, four frequencies) and ST $(0.28 \%$, two frequencies), the subjection of the male towards the female were recorded, whereas for A3 (mutilation of body parts of a crab) and A4 (death of a crab by confrontation no activity was recorded). The highest combativeness between sexes was seen at $2 \mathrm{~h}$, as follows: $\mathrm{A} 0(\mathrm{C}=6.51 \%, 46$ frequencies; $\mathrm{ST}=13.88 \%$, 98 frequencies; $\mathrm{LT}=6.51 \%, 46$ frequencies), with the main response coming from those crabs under A1 level of aggressiveness $(\mathrm{C}=10.19 \%, 72$ frequencies; $\mathrm{ST}=$ $23.71 \%, 165$ frequencies; LT $=17.56 \%, 124$ frequencies), and a reduction in $\mathrm{A} 2(\mathrm{C}=0.70 \%$, five frequencies; ST and LT $=7.08 \%, 50$ frequencies). Aggressiveness between males and females decreased in intensity in the treatments after $24 \mathrm{~h}$, where A0 type of aggressiveness was only seen in the LT $(0.28 \%$, four 
frequencies), while in the control and ST was not seen. A1 type of aggressiveness was registered in ST $(0.28 \%$, two frequencies), LT $(0.56 \%$, four frequencies $)$, and in the control group $(0.14 \%$, one frequency), while $\mathrm{A} 3$ and A4 levels of aggressiveness were not recorded (Fig. 1). There were significant differences at $2 \mathrm{~h}$ in the ST treatment in the aggressiveness scale A1 (prickling among crabs and chelae releasing, with $23.37 \%$ and 165 frequencies concerning other treatments during the experiment $(P<0.05)$ (Table 3$)$.

\section{Food intake}

\section{Bioassays in males of $C$. arcuatus}

About the amount of food used by the ablated crabs (ST and LT) concerning the not ablated ones (control treatment), it was observed that at $10 \mathrm{~min}$, the control treatment and the ST presented similar food intake values of fish fillet with $8.57 \%$, whereas the LT showed a higher value $17.14 \%$ with regards to the control treatment. At $2 \mathrm{~h}$ the ablated crabs consumed more food $(\mathrm{ST}=12.0 \% ; \mathrm{LT}=16.0 \%)$ in relation to the not ablated individuals $(\mathrm{C}=8.0 \%)$, while males from the control treatment and LT showed similar values $(7.42 \%)$ and different with regard to ST after $24 \mathrm{~h}(14.85 \%)$ (Table 4). As for survival at the end of the bioassay the values were: $\mathrm{C}=86.66 \%, \mathrm{ST}=93.33 \%$, and $\mathrm{LT}=93.33 \%$.

\section{Bioassay of females of $\boldsymbol{C}$. arcuatus}

For females, food intake was higher in the ablation treatments $(\mathrm{LT}=19.73 \%, \mathrm{ST}=11.84 \%)$ in relation to the control treatment $(7.89 \%)$ at $10 \mathrm{~min}$. After $2 \mathrm{~h}$, the same trend was seen; for LT, we obtained $14.73 \%$, and for ST, we got $11.05 \%$; males showed higher values for food intake concerning the organisms in the control treatment $(7.37 \%)$. At $24 \mathrm{~h}$, the control treatment and the LT registered low values $(6.84 \%)$ with regards to the ST (13.68\%) (Table 4). As for survival, by the end of the bioassay, the values obtained were as follows: $\mathrm{C}$ $=86.66 \%, \mathrm{ST}=86.66 \%$, and $\mathrm{LT}=93.30 \%$.

\section{Bioassay of male-females of $\boldsymbol{C}$. arcuatus}

When comparing food intake of not ablated crabs against ablated ones, the highest values were recorded for the control treatment and the LT (12.89\%) at 10 min, concerning the ST, which showed a lower value $(8.59 \%)$. At $2 \mathrm{~h}$, the treatments with ablated individuals $(\mathrm{LT}=18.62 \%$; ST $11.17 \%)$ presented a higher food intake than the control treatment (7.44\%). After $24 \mathrm{~h}$, the same trend occurred, with more food intake for the LT with $12.60 \%$ and ST with $9.46 \%$, unlike $6.30 \%$ from the control treatment (Table 4). As for survival by the end of the bioassay, the values recorded were $\mathrm{C}=$ $86.66 \%, \mathrm{ST}=93.33 \%$, and $\mathrm{LT}=93.33 \%$.

\section{Courtship and mating}

Courtship was only seen in the male-females bioassay where ST $(0 \mathrm{~h}=5 ; 2 \mathrm{~h}=4 ; 24 \mathrm{~h}=4)$, showed the highest number of partners in the three periods of observation in relation to LT $(0 \mathrm{~h}=4 ; 2 \mathrm{~h}=3 ; 24 \mathrm{~h}=3)$ and the control treatment $(0 \mathrm{~h}=2 ; 2 \mathrm{~h}=4 ; 24 \mathrm{~h}=2)$ (Table 4). As for mating, the ST had the highest number of partners (8), whereas LT only showed (6), and the lowest one was observed in the control treatment (3) (Table 4).

\section{DISCUSSION}

Ablation of the eyestalk is one of the most common methods to induce and stimulate gonadal development, the molting process, and growth in crustaceans (Allayie et al. 2011, Wen et al. 2015). This technique involves removing the ocular peduncle by several procedures that cause different effects in the species of crustaceans (Diarte-Plata et al. 2012). There is clear evidence that crustaceans experience adverse sensory effects caused by a stimulus that results in tissue damage (Zimmerman 1986, Sherwin 2001, Dunlop \& Laming 2005). In our research, we observed that when ablating the eyestalk of crabs of $C$. arcuatus, we caused an injury, which was manifested in behaviors different from those commonly observed in organisms in captivity that have not been under any procedure. Two ablation techniques were used: squash (ST) and ligation (LT), evaluating the effect on the reproductive behavior of crabs $C$. arcuatus under laboratory conditions.

According to the results obtained in the three bioassays, it was observed that LT had a higher impact on the crabs since this type of ablation caused an active rubbing of the traumatized area, even with the use of xylocaine, therefore being more stressful than ST. So this procedure gave rise to a greater response in the crabs in activities such as feeding, disorientation, and inactivity, and there were fewer movement actions in the ST concerning the control treatment.

Diarte-Plata et al. (2012) mention that prawns of Macrobrachium americanum present alterations related to the standard behavior in aspects such as shelter, disorientation, receding, and feeding behavior, and these types of abnormalities are seen in other species of crustaceans such as M. nobilli (Mariappan \& Balasundaram 2003), Macrobrachium spp. (Balasundaram et al. 2004) and Penaeus vannamei (Taylor et al. 2004). 
Table 4. Evaluation of the effect of unilateral ocular ablation on food consumption, courtship, and copulation of reproducers of the crab Callinectes arcuatus under laboratory conditions. Data are presented as an average. C: control, ST: squash ablation treatment, LT: ligation ablation treatment.

\begin{tabular}{|c|c|c|c|}
\hline \multicolumn{4}{|c|}{ Ablation bioassay: males } \\
\hline & \multicolumn{3}{|c|}{ Food consumption $(\mathrm{g})$} \\
\hline & $10 \mathrm{~min}$ & $2 \mathrm{~h}$ & $24 \mathrm{~h}$ \\
\hline Control & $8.57 \%$ & $8.00 \%$ & $7.42 \%$ \\
\hline ST & $8.57 \%$ & $12.00 \%$ & $14.85 \%$ \\
\hline LT & $17.14 \%$ & $16.00 \%$ & $7.42 \%$ \\
\hline \multicolumn{4}{|c|}{ Ablation bioassay: females } \\
\hline \multicolumn{4}{|c|}{ Food consumption (g) } \\
\hline Control & $7.89 \%$ & $7.37 \%$ & $6.84 \%$ \\
\hline ST & $11.84 \%$ & $11.05 \%$ & $13.68 \%$ \\
\hline LT & $19.73 \%$ & $14.73 \%$ & $6.84 \%$ \\
\hline \multicolumn{4}{|c|}{ Ablation bioassay: males-females } \\
\hline \multicolumn{4}{|c|}{ Food consumption $(\mathrm{g})$} \\
\hline Control & $12.89 \%$ & $7.44 \%$ & $6.30 \%$ \\
\hline ST & $8.59 \%$ & $11.17 \%$ & $9.46 \%$ \\
\hline LT & $12.89 \%$ & $18.62 \%$ & $12.60 \%$ \\
\hline \multicolumn{4}{|c|}{ Courtship (couples) } \\
\hline Control & $2(6.45 \%)$ & $4(12.90 \%)$ & $2(6.45 \%)$ \\
\hline ST & $5(16.12 \%)$ & $4(12.90 \%)$ & $4(12.90 \%)$ \\
\hline LT & $4(12.90 \%)$ & $3(9.67 \%)$ & $3(9.67 \%)$ \\
\hline \multicolumn{4}{|c|}{ Copulation (couples) } \\
\hline Control & $1(5.88 \%)$ & $1(5.88 \%)$ & $1(5.88 \%)$ \\
\hline ST & $3(17.64 \%)$ & $3(17.64 \%)$ & $2(11.76 \%)$ \\
\hline LT & $2(11.76 \%)$ & $2(11.76 \%)$ & $2(11.76 \%)$ \\
\hline
\end{tabular}

Feeding is an action that depends on factors such as molting, reproduction, and food availability. Respiratory metabolism, measured as oxygen consumption, is the best indicator of energy use. When combined with the assimilation of nutrients, it becomes a good estimator of an organism's energy needs (Dame \& Vernberg 1982). In this work, after ablation (ST and LT), C. arcuatus crabs began to ingest food immediately, contrary to what was observed in the control treatment, where the food was ingested after the first minutes of being placed in the tanks. In the bioassays of males and male/females subjected to ablation, the response of organisms in the movement of chelae and oral maxillipeds showed a lower consumption of food (fish fillet pieces) concerning females showed greater activity in the diet in the LT. The crabs from the control treatments in the three bioassays showed a minor response in the feeding activity concerning the crabs that underwent ablation treatments (Fig. 1).

During the observation time, when eating food (subgroup), the movement of the left and right oral appendages was the action most performed compared to what was recorded in the three bioassays controls, showing normal activity compared to the response ablated treatments maybe since crabs were not subjected to alteration of the eyestalk, which did not cause any discomfort to the organisms. Maggioni et al. (2004) mention that the eyestalk ablation affects the digestibility of nutrients and energy availability. Besides, the energetic needs associated with ablation are determined by sex and are related to the amount of energy channeled to reproduction. The measures of change that cross both parameters in terms of the energy balance in the ablated organisms indicate the amount of energy needed to meet survival and reproductive maturity (Chamberlain \& Lawrence 1981).

This type of behavior is common in species of shrimp subjected to unilateral ablation such as $P$. vanname $i$ and Macrobachium lanchesteri (Ponnuchmany et al. 1980, Taylor et al. 2004), where the food intake signal is driven by an increase in energy demand for the functioning of the endocrine system (Keller \& Sedlmeier 1988, Cheng 1992). The demand gives the signal for ingestion for energy through the endocrine system (Cheng 1992), and the main hormone involved in the crustacean hyperglycemic hormone $(\mathrm{CHH})$, which promotes glycogenesis in the digestive gland (Keller \& Sedlmeier 1988, Santos \& Keller 1993). When eyestalk ablation is performed, the metabolism is altered, glucose is stored as glycogen, and the cellular demand for glucose increases without the possibility of generating hyperglycemia by the action of $\mathrm{CHH}$ (Keller 
\& Sedlmeier 1988, Santos et al. 1988, Santos \& Keller 1993).

In most experiments involving eyestalk ablation, there is a clear increase in feeding to meet the energy demand. What is not clear is whether the effect of eliminating the XOSG is immediate, promoting a fast intake, which could help explain the results observed in this study. Sochasky et al. (1973) and Castell et al. (1976) demonstrated that the nutritional quality of diets could play an important role in the growth and survival of ablated organisms.

In the movement (group), in the ST at $2 \mathrm{~h}$, females showed increased activity in swimming from side to side, upwards, and walking towards the front of the tank, concerning the control treatment. Similarly, these actions occurred in males, and male/female's bioassays response was lower in this behavior. Primavera (1983) suggests that females undergoing peduncle ablation, showing a circular swimming pattern, indicate trauma. One hour after ablation, some of this behavior was still evident, but it had stopped within $24 \mathrm{~h}$ of performing the procedure. Another factor that may affect swimming behavior is anesthesia before ablating the eyestalk, which causes a decrease in the recovery time and can indicate the incidence of injuries that added to the stressful situation of crabs subjected to ablation (Taylor et al. 2004). In this study, the use of xylocaine as anesthesia could have decreased the stress caused by the eyestalk ablation, allowing the crabs to have a more normal swimming behavior, and therefore avoiding the presence of injuries in the organisms.

Those crabs in the control treatment were less affected in their movement, which could be as they were not subjected to pain stress or hormonal changes caused by ablation. This type of behavior was similar in the controls of the three bioassays (Fig. 1). Broom (2001) described pain as "an aversive sensation and feeling, associated with actual or potential tissue damage".

Pain has two key components; first, nociception can detect harmful stimuli and provides information on tissue damage, allowing a reflex response that allows the animal to move everything, or simply the affected part of its body (Fiorito 1986). In addition, the ability to feel pain is an advantage for organisms allowing them to have more chances of surviving and have a good physiological condition, thus improving their reproductive success compared to those who cannot experience pain (Fiorito 1986, Broom 2000, Sherwin 2001). Second, disorientation, which is the loss of the notion of time and space, manifesting itself through the presence of anatomical alterations or in the function of the central nervous system (Diarte-Plata et al. 2012).
In this investigation, after the ablation procedure, unablated $C$. arcuatus crabs (control) had a higher response in the male/females bioassay. Females subjected to ST, compared to males, showed more affinity to retreating to the tank walls after $2 \mathrm{~h}$. Moreover, walked in a zig-zag (Fig. 1), with a higher response in unablated crabs than in ablated ones, a behavior that differs from what was reported by DiartePlata et al. (2012), who observed that in $M$. americanum female and male control groups did not exhibit disorientation, rubbing or tail movement, as they were not subjected to pain stress. This type of procedure also showed alterations in $P$. vannamei (Taylor et al. 2004)

As for the lack of movement or activity (inactivity), those females and males under ST spent more time at rest and in the shelters after the eyestalk ablation with regards to the crabs in the control treatment, which was also reported by Diarte-Plata et al. (2012). These authors observed that the females of $M$. americanum of the control group sought refuge after having the eyestalk removed, indicating that the crabs were under stress.

In the male/females bioassay, a greater number of organisms in the LT were observed at rest, and inside the shelters, it was noticed that once the male crabs were placed in the tanks after been subjected to the ablation, they looked for females to mount, remaining at rest for a longer period, compared to the bioassays of females and males which initiated courtship. Christy (1987) defines courtship and copulation as part of the mating activities since based on the qualitative differences in how males compete with females, establishing three strategies: 1) direct defense of receptive females, 2) defense of resources needed for the females (for example shelters or sites to copulate), and 3) direct competition between males struggling to access or find females. Jivoff et al. (2007) mention that the mating of Callinectes sapidus involves intricate interactions between males and females and between competing males before, during, and after mating.

Aggressiveness is an important aspect that should be considered in managing breeders in aquaculture conditioning (Taylor et al. 2004, Xiao-Zhen et al. 2019). In the present study, aggressiveness was evaluated using a behavioral scale (A0 to A4), in which there were significant differences between the aggressiveness scales in the ablation treatments concerning the control treatment $(P<0.05)$, with greater activity in levels $\mathrm{A} 0$ to $\mathrm{A} 2$, which consisted of aspects such as "confrontation among crabs without touching each other", prickling among crabs and chelae releasing", "subjection for a short period" (Table 1). 
Concerning the control treatment (no ablation), levels A3 and A4 in the aggressiveness scale were seen.

In both eyestalk ablation treatments by ST and LT, the aggressiveness registered in the present study showed low levels of aggressiveness. It could have been caused by applying xylocaine (anesthesia) in the eyestalk before performing the ablation, as has been reported for other species of crustaceans where anesthetics have been used to decrease the aggressiveness indicators known as agonistic behaviors.

The agonistic behavior is influenced by both intrinsic (e.g. sex, body, and chela size variations and reproductive state) and extrinsic (e.g. shelter, food, mating opportunity, and mating territory) factors. Different pairwise tests, including male-male, malefemale and female-female, display different fighting abilities (Taylor et al. 2004, Dissanayake et al. 2009, Xiao-Zhen et al. 2019), considering this, in the crab $C$. arcuatus (Table 3 ) in the bioassay with males, in time $\mathrm{T} 2(2 \mathrm{~h})$ there were significant differences between the aggressiveness scale (A0-A4) for the control, ST and LT treatments $\left(\chi^{2}\right.$ pool $=104.1034 ; \chi^{2}$ critical $=30.612$; $P<0.05)$, particularly in scale A1 where a high significance was observed $\left(\chi^{2}=37.0062\right)$. Concerning the bioassay with females, in T0 $(10 \mathrm{~min})$, there were significant differences $\left(\chi^{2}\right.$ pool $=43.7138 ; \chi^{2}$ critical $=$ 30.612; $P<0.05)$ among treatments, where the scale A4 recorded the highest significance $\left(\chi^{2}=21.00\right)$ in comparison with other aggressiveness in T0.

However, in T2 (2 h), there was a lower significance for scale A4 $\left(\chi^{2}=2.6734\right)$, whereas, in T3 $(24 \mathrm{~h})$, no aggressiveness behavior was recorded in scale A4, which corresponds with what was reported by XiaoZhen et al. (2019). In the male-female bioassay, there were significant differences in T2 (2h) among treatments $\left(\chi^{2}\right.$ pool $=63.8570 ; \chi^{2}$ critical $=30.612 ; P<$ $0.05)$, being the significance for scale A1 the highest $\left(\chi^{2}\right.$ $=38.0886)$, in this experiment no records of organisms with the mutilation of the body part (A3), nor confrontation between crabs causing death (A4) were registered, which indicates that in the bioassay of males-females, aggressiveness decreases as the crabs were in close contact among themselves (copulation).

Concerning food consumption, it was seen in this study as a rapid intake of fillet pieces on those crabs under ablation treatments (ST and LT). Like what was mentioned by Taylor et al. (2004), who observed that shrimps of $P$. vannamei did not present stress after ablation, as it is reduced in those organisms that are anesthetized before being manipulated, which allows the feeding conditions to be normal and thus have a better nutritional condition.
Females had a higher consumption of food (760 g), particularly the individuals ablated by ligation (LT) $(314 \mathrm{~g})$. The lowest values were recorded in the control treatment (168 g), which may have occurred because females showed greater activity in the behavior groups (feeding, movement, disorientation, rest, and aggression), which is due to the high energy demand that the females need to have a more active behavior. Also to be a signal for the endocrine system through an increase in the rate of food intake (Santos \& Keller 1993, Urbina et al. 2010), compared to males that had a consumption of $700 \mathrm{~g}$, while in the male-female interaction, it was $698 \mathrm{~g}$, being LT the treatment with more consumption in the three bioassays. The decrease in feeding opportunities during the protection stage before mating has been described in other crustaceans (Robinson \& Doyle 1985, Donaldson \& Adams 1989, Pérez \& Bellwood 1989), for instance, blue crab females $C$. sapidus, avoid long term protection before mating due to the potential costs of being observed and the decrease in the feeding opportunities (Jivoff et al. 2007).

Eyestalk ablation can cause high mortalities in crustaceans (Mauviot \& Castell 1976, Nakatani \& Otsu 1979, 1981, Trider et al. 1979, Fairfull 1980, Freeman et al. 1983). In the present study, survival was higher in the male-females bioassay and the bioassay of males, with values higher than $93 \%$ in the ablation treatments (ST and LT). In contrast, in females, survival was $87 \%$, which can be caused as the organisms used in the bioassays were in the intermolt phase to assure a higher survival probability (Gendrop-Funes \& ValenzuelaEspinoza 1995).

Amid the main causes of mortality of crabs in bioassays was cannibalism, as reported by Amador del Ángel et al. (1999). However, the greatest survival was recorded when females and males were placed together $(>95 \%)$, as the males placed the females below them, keeping them safe and thus increasing survival. According to Parker (1974), Ridley (1983), and Jivoff et al. (2007), males of $C$. arcuatus assure their access to receptive females by using precopulatory guards, physically carrying the females below them for five to seven days before mating, which has been seen in other crustaceans such as shrimp (Naskashima 1995), lobsters (Waddy \& Aiken 1991), and river crabs (Snedden 1990).

In general, the current investigation shows where the use of the anesthetic xylocaine mitigated pain and aggressiveness indicators; food consumption was improved, and the greatest aggressiveness and cannibalism was recorded within the control treatment (without ablation and xylocaine) in male-female contact in comparison with those treatments with unilateral eyestalk ablation by squash and ligation. 


\section{ACKNOWLEDGMENTS}

This work was supported by Instituto Politécnico Nacional, Mexico (Projects directed by Dr. Genaro Diarte-Plata with registers 20195593, 20200310 and 20211101). Irma Vargas Tellez for the doctorate's scholarship given by CONACYT (CVU 822653). We would like to thank Dr. Mercedes Eugenia GuerreroRuíz for the translation of the manuscript into English.

\section{REFERENCES}

Aguiñaga-Cruz, C.J.A., Sainz-Hernández, J.C., FierroCoronado, J.A. \& Diarte-Plata, G. 2012. The effects of eyestalk ablation on the reproductive and immune function of female Macrobrachium americanum. Journal of Aquaculture Research \& Development, 3: 156. doi: $10.4172 / 2155-9546.1000156$

Allayie, S.A., Ravichandran, S. \& Bhart, B.A. 2011. Hormonal regulatory role of eyestalk factors on growth of heart in mud crab Scylla serrate. Saudi Journal of Biological Science, 18: 283-286.

Amador del Ángel, L.E., Lugo-Moreno, J. \& CabreraRodríguez, P. 1999. La quelotomía y la ablación ocular en la obtención de jaiba de concha suave Callinectes sapidus Rathbun en condiciones de laboratorio. Proceedings of the Gulf and Caribbean Fisheries Institute, 45: 588-599.

Balasundaram, C., Jeyachitra, P. \& Balamurugan, P. 2004. Shelter preference in Macrobrachium spp. with reference to aquaculture. Acta Ethologica, 7: 95-101. doi: 10.1007/s10211-004-0090-4

Broom, D.M. 2001. Evolution of pain. In: Lord-Soulsby, E.J.L. \& Morton, D. (Eds.). Pain: its nature and management in man and animals. Proceedings of the Royal Society of Medicine International Congress Symposium Series, 246. Royal Society of Medicine, London, pp. 17-25.

Browdy, C.L. 1992. A review of the reproductive biology of Penaeus species: perspectives on controlled shrimp maturation systems for high quality nauplii production. In: Wyban, J. (Ed.). Proceedings of the Special Session on Shrimp Farming. Florida, pp. 22-51.

Castell, J.D., Covey, J.F., Aiken, D.E. \& Waddy, S.L. 1976. The potential for eyestalk ablation as a technique for accelerating growth of lobsters (Homarus americanus) for commercial culture. Proceeding of the World Mariculture Society, 8: 895-914.

Chamberlain, G.W. \& Lawrence, A.L. 1981. Maturation, reproduction and growth of Penaeus vannamei and $P$. stylirostris fed natural diets. Journal of the World Mariculture Society, 12: 209-224. doi: 10.1111/j. 1749-7345.1981.tb00256.x
Cheng, E.S. 1992. Endocrinology. In: Lester, L.J. \& Wade, A. (Eds.). Marine shrimp culture, principles and practices. Elsevier, Amsterdam, pp. 53-91.

Choy, S.C. 1987. Growth and reproduction of eyestalk ablated Penaeus canaliculatus (Olivier, 1811) (Crustacea: Penaeidae). Journal of Experimental Marine Biology and Ecology, 112: 93-107. doi: 1016/00220981(87)90111-0

Christy, J.H. 1987. Competitive mating, mate choice and mating associations of brachyuran crabs. Bulletin of Marine Science, 42: 177-191.

Dame, R.F. \& Vernberg, F.L. 1982. Energetics of a population of mud crab Panopesu herbstii (Milne Edwards) in the North Inlet estuary, South Carolina. Journal of Experimental Marine Biology and Ecology, 63: 183-193.

Diarte-Plata, G., Sainz-Hernández, J.C., Aguiñaga-Cruz, J.A., Fierro-Coronado, J.A., Polanco-Torres, A. \& Puente-Palazuelos, C. 2012. Eyestalk ablation procedures to minimize pain in the freshwater prawn Macrobrachium americanum. Applied Animal Behaviour Science, 140: 172-178. doi: 10.1016/j. applanim.2012.06.002

Dissanayake, A., Galloway, T.S. \& Jones, M.B. 2009. Physiological condition and intraspecific agonistic behaviour in Carcinus maenas (Crustacea: Decapoda), Journal of Experimental Marine Biology and Ecology, 375: 57-63. doi: 10.1016/j.jembe.2009.05.007

Donaldson, W.E. \& Adams, A.A. 1989. Ethogram of behavior with emphasis on mating for the tanner crab, Chionoecetes bairdi Rathbun. Journal of Crustacean Biology, 9: 37-51.

Dunlop, R. \& Laming, P. 2005. Mechanoreceptive and nociceptive responses in the central nervous system of goldfish (Carassius auratus) and trout (Oncorhynchus mykiss). Journal of Pain, 6: 561-568. doi: 10.1016/ j.jpain.2005.02.010

Fairfull, R.W. 1980. The genetics and early growth of lobsters (Homarus americanus) as related to rearing under artificial conditions. Ph.D. Thesis, Dalhousie University, Halifax.

Fenucci, J.L. 1988. Manual para la cría de camarones peneidos. FAO, Documentos de Campo, 8: 88 pp.

Fingerman, M. 1987. The endocrine mechanisms of crustaceans. Journal of the Crustacean Biology, 7: 124. doi: $10.2307 / 1548622$

Fingerman, M. 1997. Crustacean endocrinology. A retrospective, prospective, and introspective analysis. Physiological Zoology, 70: 257-269.

Fiorito, G. 1986. Is there 'pain' in invertebrates? Behavioral Processes, 12: 383-388. 
Food and Agriculture Organization (FAO). 2014. El estado mundial de la pesca y la acuicultura. FAO, Rome.

Freeman, J.A., West, T.L. \& Costlow, J.D. 1983. Postlarval growth in juvenile Hithrapanopeus harrisii. Biological Bulletin, 165: 409-415. doi: 10.2307/1541 205

Gendrop-Funes, V. \& Valenzuela-Espinoza, E. 1995. Ablation unilateral of Penaeus stylirostris (Stimpson). Ciencias Marinas, 21: 401-413.

Jivoff, P., Hines, A.H. \& Quackenbush, L.S. 2007. Reproduction biology and embryonic development. In: Kennedy, V.S. \& Cronin, L.E. (Eds.). The blue crab Callinectes sapidus. Maryland Sea Grant, Maryland, pp. 255-298.

Juinio-Meñez, M.A. \& Ruinata, J. 1996. Survival, growth and food conversion efficiency of Panulirus ornatus following eyestalk ablation. Aquaculture, 146: 225235. doi: 10.1016/S0044-8486(96)01371-3

Keller, R. \& Sedlmeier, D.A. 1988. Metabolic hormone in crustaceans: the hyperglycemic neuropeptide. In: Laufer, H. \& Downer, R. (Eds.). Endocrinology of selected invertebrate types, invertebrate endocrinology. Liss, New York, pp. 315-326.

Lachaise, F., Carpenter, G., Somme, G., Colardeau, J. \& Beydon, P. 1989. Ecdysteroid synthesis by crab Yorgans. Journal of Experimental Zoology, 252: 283292. doi: 10.1002/jez.1402520311

Maggioni, D.S., Andreatta, E.R., Hermes, E.M. \& Barracco, M.A. 2004. Evaluation of some hematoimmunological parameters in female shrimp Litopenaeus vannamei submitted to unilateral eyestalk ablation in association with a diet supplemented with super doses of ascorbic acid as a form of immunostimulation. Aquaculture, 241: 501-515. doi: 10.1016/ S0044-8486(03)00530-1

Makinouchi, S. \& Primavera, H. 1987. Maturation and spawning of Penaeus indicus using different ablation methods. Aquaculture, 62: 73-81. doi: 10.1016/00448486(87)90186-4

Mariappan, P. \& Balasundaram, C. 2003. Sheltering behavior of Macrobrachium nobilii (Henderson and Matthai, 1910). Acta Ethologica, 5: 89-94. doi: 10.1007/s10211-002-0069-y

Mauviot, J.C. \& Castell, J.D. 1976. Molt and growth enhance effects of bilateral eyestalk ablation on juvenile and adult American lobsters (Homarus americanus). Journal of the Fisheries Research Board of Canada, 33: 1922-1929. doi: 10.1139/f76-245

Momin, M.A. \& Rangneker, P.V. 1975. Histochemical patterns of lipolytic enzymes of the hepatopancreas of Scylla serrata and their possible relation to eyestalk factor(s). Zoological Journal of the Linnean Society, 57: 75-84. doi: 10.1111/j.1096-3642.1975.tb01891.x
Mykles, D.L. 2001. Interactions between limb regeneration and molting in decapod crustaceans. American Zoologist, 41: 399-406.

Nakashima, Y. 1995. Can small male shrimps achieve copulation in the presence of larger ones? Journal of Ethology, 13: 9-16.

Nakatani, I. \& Otsu, T. 1979. The effects of eyestalk, leg, and uropod removal on the molting and growth of young crayfish, Procambarus clarkii. Biological Bulletin, 157: 182-188. doi: 10.2307/1541086

Nakatani, I. \& Otsu, T. 1981. Relations between the growth and the molt interval in the eyestalkless crayfish, Procambarus clarkii. Comparative Biochemistry and Physiology - Part A: Molecular \& Integrative Physiology, 68: 553-594. doi: 10.1016/03009629(81)90360-1

Ogle, J. 1991. Maturation of Penaeus vannamei based upon a survey. Gulf and Caribbean Research, 8: 296297.

Palacios, E., Carreoño, D., Redríguez-Jaramillo, M. \& Racotta, I. 1999. Effect of eyestalk ablation on maturation, larval performance, and biochemistry of white pacific shrimp, Penaeus vannamei, broodstock. Journal of Applied Aquaculture, 9: 1-23.

Parker, G.A. 1974. Courtship persistence and femaleguarding as male time investment strategies. Behaviour, 48: 157-184.

Perez, O.S. \& Bellwood, D.R. 1989. Observations on the mating behaviour of the Indo-Pacific sandy shore crab Matuta lunaris (Forskal) with notes on the reproductive behaviour of the Matutinae (Decapoda, Brachyura, Calappidae). Crustaceana, 57: 1-9.

Ponnuchamy, R., Ravichandra, R. \& Shakuntala, K. 1980. Effects of eyestalk ablation on growth and food conversion efficiency of the freshwater prawn Macrobrachium lanchesteri (De Man). Hydrobiologia, 77: 77-80. doi: 10.1007/BF00006391

Primavera, J.H. 1983. Broodstock of sugpo, Penaeus monodon Fabricius. Extension manual 7. Southeast Asian Fisheries Development Center, Tigbauan.

Quackenbush, L.S. 1991. Regulation of vitellogenesis in penaeid shrimp. In: DeLoach, P.F., Davidson, M.A. \& Dougherty, W.J. (Eds.). Frontiers of shrimp research. Elsevier Science Publishers, Amsterdam, pp.125-140.

Quackenbush, L.S. 1994. Lobster reproduction: a review. Crustaceana, 67: 82-94.

Racotta, I., Palacios, E. \& Carreño, D. 1998. Effect of ablation on reproductive performance and biochemical composition of eggs, nauplii, and spawner tissues in Penaeus vannamei. Proceedings of the Symposium held in Brest, 19-20 November 1998, vol. 27. IFREMER, Plouzane. 
Rajesh, B. \& Laxminaryana, A. 1993. Metabolic effects of eyestalk removal in Penaeus indicus $\mathrm{H}$. Milne Edwards. Mariculture Research under the Postgraduate Programme in Mariculture: Part 2. CMFRI Special Publication, 53: 76-79.

Ridley, M. 1983. The explanation of organic diversity: the comparative method and adaptations for mating. Clarendon Press, Oxford.

Robinson, B.W. \& Doyle, R.W. 1985. Trade-off between male reproduction (amplexus) and growth in the amphipod Gammams lawrendanus. Biological Bulletin, 168: 482-488. doi: 10.2307/1541528

Rosas, C., Fernandez, I., Brito, R. \& Diaz-Iglesia, E. 1993. The effect of eyestalk ablation on the energy balance of the pink shrimp, Penaeus notialis. Comparative Biochemistry and Physiology - Part A: Molecular \& Integrative Physiology, 104: 183-187. doi: 10.1016/ 0300-9629(93)90027-2

Santos, E.A. \& Keller, R. 1993. Regulation of circulating levels of the crustacean hyperglycemic hormone: evidence for a dual feedback control system. Journal of Comparative Physiology - Part B: Biochemistry \& Molecular Biology, 163: 374-379. doi: 10.1007/ BF00265641

Santos, E.A., Nery, L.E.M. \& Manzini, G.C. 1988. Action of the crustacean hyperglycemic hormone of Chasmagnatus granulata (Dana, 1851) (Decapoda: Grapsidae). Comparative Biochemistry and Physiology - Part A: Molecular \& Integrative Physiology, 89: 329-332. doi: 10.1016/0300-9629(88)91034-1

Sherwin, C.M. 2001. Can invertebrates suffer? Or how robust is argument-by-analogy? Animal Welfare, 10: 103-118.

Shinozaki-Mendes, A., Manghi, R.F. \& Lessa, R. 2013. Comparative study of the molting cycle of wild and reared swimming crabs Callinectes danae (Crustacea: Portunidae). Journal of Applied Ichthyology, 30: 502506. doi: 10.1111/jai.12236

Snedden, W.A. 1990. Determinants of male mating success in the temperate crayfish Orconectes rusticus: chela size and sperm competition. Behaviour, 115: 100- 113.

Sochasky, J.B., Aiken, D.E. \& McLeese, D.W. 1973. Does eyestalk ablation accelerate molting in the lobster \& Lomarus americanus? Journal of Fisheries Research Board of Canada, 30: 1600-1603.

Subramoniam, T. 2000. Mechanism and control of vitellogenesis in crustaceans. Fisheries Science, 77: 1-21. doi: 10.1007/s12562-010-0301-Z

Taketomi, Y., Nishino, M., \& Yoshizumi, K. 1997. Effects of eyestalk hormone on the androgenic glands of the shrimp Neocaridina denticulata. Proceedings of the XIII International Congress of Comparative Endocrinology, Japan, pp. 79-82.
Taylor, J., Vinatea, L., Ozorio, R., Schuweitzer, R. \& Andreatta, E.R. 2004. Minimizing the effects of stress during eyestalk ablation of Litopenaeus vannamei females with topical anesthetic and a coagulating agent. Aquaculture, 233: 173-179. doi: 10.1016/j. aquaculture.2003.09.034

Techa, S., Álvarez, J.V. \& Sook-Chung, J. 2015. Changes in ecdysteroid levels and expression patterns of ecdysteroid-responsive factors and neuropeptide hormones during the embryogenesis of the blue crab, Callinectes sapidus. General and Comparative Endocrinology, 214: 157-166. doi: 10.1016/j.ygcen. 2014.07.017

Travis, D.F. 1952. The control of the sinus gland over certain aspects of calcium metabolism in Pamaneus areus. Anatomical Record, 11: 503.

Trider, D.J., Mason, E.G. \& Castell, J.D. 1979. Survival and growth of juvenile American lobsters (Homarus americanus) after eyestalk ablation. Journal of Fisheries Board of Canada. 36: 93-97. doi: 10.1139/ f79-015

Tsukimura, B. 2001. Vitellogenesis: its role in oocyte development. American Zoology, 41: 465-476. doi: 10.1093/icb/41.3.465.

Urbina, M., Paschke, K., Gebauer, P. \& Chaparro, O.R. 2010. Physiological energetics of the estuarine crab Hemigrapsus crenulatus (Crustacea: Decapoda: Varunidae): responses to different salinity levels. Journal of the Marine Biological Association of the United Kingdom, 90: 267-273. doi: 10.1017/S00253 15409990889

Waddy, S.L. \& Aiken, D.E. 1991. Mating and insemination in the American lobster, Homarus americanus. In: Bauer, R.T. \& Martin, J.W. (Eds.). Crustacean sexual biology. Columbia University Press, New York, pp. 126-144.

Webster, S.G. \& Keller, R. 1986. Purification, characterization and amino acid composition of the putative moult-inhibiting hormone (MIH) of Carcinus maenas (Crustacea, Decapoda). Journal of Comparative Physiology - Part B: Biochemistry \& Molecular Biology, 156: 617-624. doi: 10.1007/BF00 692738

Wen, W., Yang, Q., Ma, Z., Jiang, S. \& Qui, L. 2015. Comparison of ovarian maturation and spawning after unilateral eyestalk ablation of wild-caught and pondreared Penaeus monodon. Spanish Journal of Agricultural Research, 13: e0402. doi: 10.5424/sjar/20 15133-7860

Xiao-Zhen, Y., Yang-Yang, P., Gen-Yong, H., Min-Jie, X., Cong, Z., Long, H., et al. 2019. The serotonin or dopamine by cyclic adenosine monophosphate-protein kinase A pathway involved in the agonistic behaviour of Chinese mitten crab, Eriocheir sinensis. Physiology \& Behavior 209: 1-8. doi: 10.1016/j.physbeh.2019. 112621 
Zaib-Un-Nisa, N. \& Ahmed, M. 2001. Natural and induced spawning of Pakistani penaeid shrimps in the laboratory. Pakistan Journal of Zoology, 33: 125-130.

Zar, J.H. 2010. Biostatistical analysis. Prentice-Hall, New Jersey.

Received: December 15, 2020; Accepted: March 3, 2021
Zimmerman, M. 1986. Physiological mechanism of pain and its treatment. Klinische Anasthesiol Intensivther, 32: 1-19.

Zmora, O., Findiesen, A., Stubblefield, J., Frenkel, V. \& Zohar, Y. 2005. Large-scale juvenile production of the blue crab Callinectes sapidus. Aquaculture, 244: 129139. doi: 10.1016/j.aquaculture. 2004.11.012 